\title{
Substrate Moisture Content Effects on Growth and Shelf Life of Angelonia angustifolia
}

\author{
Alison Bingham Jacobson, Terri W. Starman', \\ and Leonardo Lombardini \\ Department of Horticultural Sciences, Texas A\&M University, 2133 TAMU, \\ College Station, TX 77843-2133
}

Additional index words. bedding plants, drought, irrigation, postharvest, water

\begin{abstract}
Wilting during shelf life is a major cause of postharvest shrink for bedding plants shipped long distances from production greenhouses to retail outlets. The objective of this research was to determine if irrigation at lower, constant substrate moisture content (SMC) during greenhouse production would be a feasible way to acclimate plants for reduced shrinkage during shelf life while potentially conserving irrigation water. In two separate experiments conducted in the fall and spring seasons, rooted plugs of Angelonia angustifolia 'Angelface Blue' (angelonia) were grown in greenhouse production until a marketable stage in substrates irrigated at SMC levels of $10 \%, 20 \%, 30 \%$, and $40 \%$ using a controlled irrigation system. At the end of the greenhouse production stage, plants were irrigated to container capacity and subjected to a simulated shipping environment in shipping boxes in the dark for 2 days. After shipping, plants were placed back in the greenhouse and watered minimally to simulate a retail environment. Data were taken at the end of each stage, i.e., greenhouse production, simulated shipping, and simulated retail. Results indicated that as SMC decreased from $40 \%$ to $10 \%$, plants were shorter in height but had proportional and more compact flowering sections. The volume of water received by the $40 \%$ SMC plants was three times greater (fall) and 12 times greater (spring) than the $20 \%$ SMC plants during greenhouse production and two times greater (fall) and nine time greater (spring) during simulated retail. During production, midday water potentials decreased as the SMC levels decreased, but at the end of the simulated retail, the midday water potentials were the same, suggesting that plants that were drought-stressed during production were acclimated to lower water levels experienced in retail settings. Overall, the $20 \%$ SMC treatment produced the best postharvest quality plant resulting from reduced plant height without detrimental effects on flowering. The results demonstrate that while conserving water, controlled irrigation at a lower SMC can produce high-quality plants that have equal shelf life to those that are irrigated at high levels.
\end{abstract}

Retail environments for marketing floriculture crops have a wide range of light levels and temperature. One common characteristic is that irrigation is almost never optimum as a result of untrained personnel or understaffing. Watering practices at retail venues may be indiscriminate, i.e., all plants are watered on the same time schedule regardless of their need resulting in some plants being overwatered and some underwatered. Conversely, watering may be limited, i.e., plants are allowed to wilt before they are watered. Either watering regimen is detrimental to plant health and hastens their decline in postharvest quality and shelf life at the retail level.

Hardening off, or toning, at the end of the greenhouse production cycle by reducing fertilizer rate, temperature, light intensity, and soil moisture levels is a practice that has long been known to increase shelf life of

Received for publication 26 Aug. 2014. Accepted for publication 14 Nov. 2014.

${ }^{1}$ To whom reprint requests should be addressed; e-mail tstarman@tamu.edu.
(Rosa xhybrida 'Charming' and 'Bianca Parade'), it was found plants were better able to survive periods of inadequate water during postproduction when water consumption was lower during production (Williams et al., 2000). Rose plants watered at the highest water level had higher water contents but tended to wilt sooner than plants grown with reduced water.

Petunias (Petunia $\times$ hybrida) grown at three irrigation frequencies during production and then evaluated in three postproduction temperatures $\left(10 / 10,20 / 20\right.$, or $30 / 20{ }^{\circ} \mathrm{C}$ day/night) declined in quality most rapidly and had the greatest number of senesced flowers in the moderate and warm postproduction environments when they had been irrigated at the highest frequency. Conversely, plants irrigated less frequently had slower flower development but had reduced number of senesced flowers, greater dry weight, and an overall better visual quality regardless of postproduction temperature to plants irrigated more frequently (Armitage and Kowalski, 1983).

Greenhouse irrigation systems have become more efficient in water conservation while still maintaining floriculture crop quality. Constant SMC was reliably maintained for impatiens (Impatiens walleriana), petunia, salvia, and vinca for an extended period of time despite varying plant sizes with little to no runoff and wastage of water (Nemali and van Iersel, 2006). By maintaining SMC, the irrigation system effectively replaced the water that was lost by evapotranspiration, thus creating a plant-driven system (Burnett and van Iersel, 2008). This type of irrigation system could make it easier for growers to limit water during production to only that needed by the plant to maintain quality and plant health that is sustainable throughout the market channels.

The objective of the present research was to determine the effect of four levels of constant SMC during greenhouse production followed by one of two postproduction irrigation regimens during simulated retail: 1) indiscriminate (all plants watered the same); or 2) limited (plants allowed to wilt before watering) on growth and subsequent shelf life of angelonia (Angelonia angustifolia) 'Angelface Blue'. Our hypothesis was that lower, constant SMC during greenhouse production would acclimate or "condition" plants for the two simulated retail watering regimens while conserving irrigation, fertilization, and plant quality during production and marketing.

\section{Materials and Methods}

Rooted cuttings of angelonia 'Angelface Blue' were obtained from a commercial propagator (EuroAmerican, Bonsall, CA) and graded for uniformity. Sixteen 16-L $(28.1 \mathrm{~cm}$ wide, $45.7 \mathrm{~cm}$ long, $18.3 \mathrm{~cm}$ deep) plastic containers (Iris USA Inc., Pleasant Prairie, WI) were used to hold root substrate (Sunshine LC1 mix; SunGro Horticulture, Bellevue, WA) rather than commercial pots. These containers were necessary to accommodate the size of the 
Acclima time domain transmissometry sensors ( $5.4 \mathrm{~cm}$ wide, $20.3 \mathrm{~cm}$ long, $1.4 \mathrm{~cm}$ deep) (Acclima, Inc., Meridian, ID). The exterior surface of each container was sprayed with silver paint to restrict light penetration and algae growth within the containers. Additionally, holes were drilled at the bottom of each container to allow drainage. Fifty-four grams $\left(2.6 \mathrm{~kg} \cdot \mathrm{m}^{-3}\right)$ of $15 \mathrm{~N}-3.9 \mathrm{P}-9.9 \mathrm{~K}$ slow-release fertilizer (Osmocote, Peters Professional; Scotts-Sierra, Marysville, $\mathrm{OH}$ ) were incorporated evenly throughout the substrate before planting. Two dribble ring emitters with a flow rate of $5.3 \mathrm{~mL} \cdot \mathrm{s}^{-1}$ (24-inch lead, 6-inch diameter) (Dramm Cooperation, Manitowoc, WI) were placed on top of the substrate and around the plants and secured with greening pins to deliver irrigation.

Plants were grown in a glass wall and polycarbonate roof greenhouse in College Station, TX, for two experiments: 1) fall (3 Sept. to 29 Oct. 2010); and 2) spring (25 Jan. to 11 May 2011). Air temperature and solar radiation were measured at plant canopy level using data loggers (WatchDog; Spectrum Technologies, Plainfield, IL) every hour and averaged into daily measurements. Temperature set points for the greenhouse were $24^{\circ} \mathrm{C}$ day $/ 18^{\circ} \mathrm{C}$ night. Average temperature in the greenhouse was $25.8^{\circ} \mathrm{C}$ day/23.1 ${ }^{\circ} \mathrm{C}$ night (fall) and $23.2{ }^{\circ} \mathrm{C}$ day $/ 20.9{ }^{\circ} \mathrm{C}$ night (spring) for the greenhouse production stage. Average light levels were $14 \mathrm{~mol} \cdot \mathrm{m}^{-2} \cdot \mathrm{d}^{-1}$ (fall) and $7 \mathrm{~mol} \cdot \mathrm{m}^{-2} \cdot \mathrm{d}^{-1}$ (spring). Average temperatures for the greenhouse during simulated retail were $24.5^{\circ} \mathrm{C}$ day $/ 22.3^{\circ} \mathrm{C}$ night (fall) and $23.7{ }^{\circ} \mathrm{C}$ day/21.9 ${ }^{\circ} \mathrm{C}$ night (spring) and average light levels were $5 \mathrm{~mol} \cdot \mathrm{m}^{-2} \cdot \mathrm{d}^{-1}$ (fall) and $12 \mathrm{~mol} \cdot \mathrm{m}^{-2} \cdot \mathrm{d}^{-1}$ (spring)

The greenhouse production stage was initiated by transplanting angelonia plants into the containers and drenching the root substrate with a fungicide to prevent root rot (Banrot, Peters Professional; Scotts-Sierra). Containers were allowed to dry down to their respective SMC treatment levels and those levels were held throughout production until plants were flowering and deemed marketable, i.e., they displayed full foliage and had three flowering stems. To give time for water to travel through the root substrate, the soak cycle was set to water for $30 \mathrm{~s}$ with an interval length between watering of $4 \mathrm{~min}$. This allowed water to percolate through the substrate, thus preventing underestimating SMC reading and excess water from being applied.

Treatments. Two experiments were conducted, in Fall 2010 (3 Sept. to 29 Oct.) and in Spring 2011 (25 Jan. to 11 May) using similar greenhouse production and simulated shipping practices but with two different irrigation regimens (indiscriminant in fall and limited in spring) during simulated retail. Each experiment consisted of three stages: 1) greenhouse production with four SMC levels; 2) simulated shipping in the dark for $48 \mathrm{~h}$; and 3) simulated retail. The four SMC treatment levels were $40 \%, 30 \%, 20 \%$, and $10 \%$ with four containers (replicates), each planted with eight plants for a total of 128 plants. The $40 \%$
SMC treatment was chosen to correspond to conventional irrigation (well-watered plant) and the $10 \%$ SMC treatment to drought stress.

To calibrate the Acclima system, three 1-L beakers were filled to a known volume with root substrate, and water was applied to the beakers in varying amounts to obtain a continuum of dry to wet media. An Acclima sensor was used to take readings in each beaker followed by weighing each beaker. The substrate was put into a drying oven (214330; Hotpack Corp., Philadelphia, PA) at $80{ }^{\circ} \mathrm{C}$ for $48 \mathrm{~h}$. Once dry, the substrate was weighed gravimetrically with a Mettler balance (PM 16; Mettler Industries Corp., Hightstown, NJ). Thresholds were determined using a calibration graph to determine the actual SMC of the substrate, which was set as the lower threshold. When the SMC dropped below the lower threshold, the water would turn on and irrigate until the SMC reached the upper threshold.

At the end of the greenhouse production stage, plants were subjected to simulated shipping. Each container was disconnected from the irrigation system, hand-watered until runoff, allowed to drain, then placed into a 38 -cm wide $\times 61-\mathrm{cm}$ long $\times 64-\mathrm{cm}$ deep cardboard shipping box. The boxes were sealed with plastic packaging tape and randomly stacked with air channels between them in the simulated shipping area in the dark at $20 \pm 2{ }^{\circ} \mathrm{C}$ for $48 \mathrm{~h}$. After $48 \mathrm{~h}$ of simulated shipping, the containers were removed from the boxes and placed back into the greenhouse where they were connected again to the irrigation system to simulate a retail environment.

The two different irrigation regimens during the simulated retail stages were 1) indiscriminate (fall experiment); or 2) limited (spring experiment). After $5 \mathrm{~d}$ (when wilting was observed on the $40 \%$ SMC treatments), all containers in the indiscriminate regimen were set to water at $20 \%$ SMC for the 3-week duration of simulated retail. For the limited regimen, all SMC treatments were automatically irrigated during retail when the first plant in any treatment wilted and then held slightly above that SMC to prevent wilting for the remainder of simulated retail. The SMC levels at which the treatments were irrigated during simulated retail were $26 \%$ SMC for the $40 \%$ treatments, $11 \% \mathrm{SMC}$ for the $30 \%$ treatments, and $7 \%$ for the $20 \%$ treatments. The $10 \%$ SMC treatment never wilted during simulated retail and therefore was never irrigated.

Irrigation system. The greenhouse production stage used an irrigation system like the one previously described by Nemali and van Iersel (2005) to measure SMC in multiple containers and trigger irrigation based on container-specific SMC thresholds. Each container had its own sensor wired to a solenoid valve to irrigate that container. SMC levels were monitored twice a day using Acclima's irrigation manager software on a laptop computer.

Data collection. Plants were moved from the greenhouse production stage into the simulated shipping stage when they were considered marketable, i.e., they displayed full foliage and had three flowering stems with open flowers. Data taken at the end of greenhouse production and/or simulated retail stages were: plant height; stem and node number; internode length; days to first flower; bud, fresh, and senesced flower number; pre-dawn and midday water potential; and a postharvest quality rating using a scale of 5 (best) to 1 (worst) but regarded as observation data (not analyzed). Fresh flower, bud, and senesced flower numbers and stem numbers were taken on every stem on every plant in a treatment. Fresh flowers were those with the reproductive flower parts visible, buds were those that petals had not parted to reveal reproductive parts, and senesced flowers were those with three or more petals wilting and still attached to the plant.

Midday and pre-dawn water potentials were taken with a pressure chamber $(3005$ series; Soil Moisture Equipment Corp., Santa Barbara, CA) by cutting a stem off one plant in each container. Pre-dawn water potentials were taken before sunrise and midday water potentials were taken between 1300 and $1400 \mathrm{HR}$.

After simulated shipping, total abscised flower number was the sum of those that had fallen into the shipping boxes and onto the root substrate surface in the growing container. Abscised flower percentage was calculated by dividing the total number of abscised flowers after shipping by the total fresh and senesced flowers attached to the plant before shipping and multiplying $\times 100$.

Fresh and dry root and shoot weights were measured gravimetrically (N1B110; Ohaus Corp, Parsippany, NJ) at the end of the simulated retail stage of the spring experiment. To determine fresh root weight, plants were cut at the substrate line and roots of each container were gently washed and separated and measured. Shoot and root dry weight was determined after drying in an oven for $48 \mathrm{~h}$ at $80{ }^{\circ} \mathrm{C}$. Shoot-to-root ratio was calculated by dividing shoot dry weight by the root dry weight of all plants in a container.

Electrical conductivity (EC) was measured once a day by the Acclima soil moisture sensors and recorded in the computer's sensor $\log$. Number and duration of irrigation events were taken from the Acclima water data logs and multiplied to get the total irrigation duration. Total volume of water applied was calculated by multiplying the total irrigation duration (in seconds) by the dribble rings flow rate of $5.3 \mathrm{~mL} \cdot \mathrm{s}^{-1}$. WUE was calculated by dividing the stem dry weight of all plants in a container by the amount of water used by a container during greenhouse production and again for simulated retail.

Leaf greenness index was measured by the non-destructive handheld chlorophyll meter [measured as the optical density, SPAD-502 reading (Minolta Camera Co., Osaka, Japan)] in the spring experiment during greenhouse production and simulated retail. The Special Products Analysis Division (SPAD) value ranged from 0 to 100 to estimate leaf 
chlorophyll content by measuring the light transmission at wavelengths of 650 and $940 \mathrm{~nm}$ (Markwell et al., 1995). SPAD readings were taken on two leaves (a new leaf that was five to six nodes down from the stem tip and a mature leaf below the basal fresh flower) of three plants in each container. The treatments in each experiment (fall and spring) were completely randomized. Data for each experiment were analyzed separately with SAS 9.2 statistical software (SAS Institute, Cary, NC) by analysis of variance and Duncan's multiple range test for mean separation. Postharvest quality data were considered objective and not analyzed.

\section{Results and Discussion}

Production. Plants in all treatments reached first open flower stage in $15 \mathrm{~d}$ from planting in the fall experiment and $35 \mathrm{~d}$ in the spring experiment (Table 1). In both experiments, the $40 \%$ SMC resulted in the tallest plants and the $10 \% \mathrm{SMC}$ resulted in the shortest plants. However, in the spring experiment, the $10 \%$ SMC plants were more stunted and not of marketable size. The $30 \%$ and $20 \%$ SMC resulted in intermediate measurements for plant height. In both experiments, $40 \%$ and $30 \%$ SMC produced the greatest number of nodes and $10 \%$ SMC the least number of nodes, whereas average internode length was the same (fall) or only slightly varied (spring) among SMC treatments.

Inhibition of growth is among the earliest responses of plants to drought (Klamkowski and Treder, 2006). Other floricultural crops such as gaura (Gaura lindheimeri) (Burnett and van Iersel, 2008), salvia (Salvia splendens) (Eakes et al., 1991), marigold (Tagetes erecta) (van Iersel and Nemali, 2004), carnation (Dianthus caryophyllus) (Álvarez et al., 2009), hibiscus (Hibiscus rosa-sinensis) (Hansen et al., 2005), and petunia (Armitage and Kowalski, 1983) had reduced plant height or stem length when they were exposed to drought stress.

In the fall experiment, higher SMC resulted in greater fresh flower and bud number and smaller senesced flower number at the end of production (Table 2). In the spring experiment, the $10 \%$ SMC treatment resulted in the smallest fresh flower number but had no difference in senesced flower number compared with other treatments. In both experiments, $40 \%$ and $30 \%$ SMC plants had the greatest number of buds; $20 \%$ SMC plants were intermediate in the fall but the same as $10 \%$ SMC plants in the spring.

In the fall experiment, the observed postharvest quality for the $10 \%$ and $40 \%$ SMC was lower than the $20 \%$ and $30 \%$ SMC as a result of the $10 \%$ SMC plants being wilted at the end of production and the $40 \%$ SMC plants being tall with a few lodging stems (Fig. 1A). The postharvest quality observations for the $20 \%$ and $30 \%$ SMC were judged as having optimal aesthetic appeal as a result of their compact size, proportional flowering stem sections, and turgid, dark green leaves.
The postharvest quality for the $30 \%$ SMC plants was high again in the spring experiment as a result of their compact size and turgid, dark green leaves. In the spring, the postharvest quality for $10 \%$ SMC was lower as a result of the plants being wilted and stunted throughout production. The postharvest quality of the $20 \%$ and $40 \%$ SMC were not as good as $30 \%$ SMC plants as a result of the $20 \%$ SMC plants being small in height and the $40 \%$ plants being tall with lodging stems.

During greenhouse production in the spring, it was observed that the $10 \%$ SMC plants had darker green leaves compared with the other SMC treatments, and this was confirmed by SPAD meter readings (Table 3). However, as greenhouse production continued, the $20 \%$ and $30 \%$ SMC plant leaves were also darker in color, resulting in the $40 \%$ SMC plant leaves being the lightest in color by the end of greenhouse production.

In the fall experiment, total volume of water applied during production for $40 \%$ SMC was 14.7 L, which was $87 \%$ more water than was applied for 10\% SMC (1.9 L) (Table 4). The 38 irrigation events for $40 \%$ SMC treatments were applied on 11 of $35 \mathrm{~d}$, whereas the 11 irrigation events for the $10 \% \mathrm{SMC}$ occurred on $2 \mathrm{~d}$. The $40 \%$ SMC plants grew taller (Table 1) and thus required more water; therefore, they were watered more frequently and the total duration of watering throughout production was longer (46 min) for these plants than the $10 \%$ SMC plants (6 min). Similar results were found in the spring experiment regarding amount of water, duration of watering, and number of irrigation events during production (Table 4). Our results are similar to impatiens, petunia, salvia, and vinca (Nemali and van Iersel, 2006) in which the highest SMC treatment (32\% SMC) received $92 \%$ more water than the lowest treatment (9\% SMC). Additionally, gaura (Burnett and van Iersel, 2008) grown at the highest SMC treatment (45\% SMC) received $93 \%$ more water than the lowest treatment (10\% SMC).

In both experiments, root substrate EC was higher in the $40 \%$ SMC than the other SMC treatments (Table 4). This could be because the $40 \%$ SMC plants received more water and therefore more salts leached from the slow-release fertilizer into the root substrate. Leachate volume correlates positively with irrigation volume, which means that more water would pass through a slow-release fertilizer capsule and more nutrients would leach out (Burnett and van Iersel, 2008). This could also explain why the $40 \%$ SMC plants were taller and toppled over. More nitrogen and phosphorus can make plants taller (Harris, 1992). However, using continuous liquid feed fertilizer and an irrigation controller induced higher EC in gaura irrigated at a lower SMC (Burnett and van Iersel, 2008).

Results of water potential measurements were similar during the spring experiment (Fig. 2) and the fall experiment (data not shown). During production, the $10 \% \mathrm{SMC}$ plants always resulted in more negative pre-dawn and midday water potential compared with the other SMC treatments (Fig. 2A and $\mathrm{B})$. At the end of greenhouse production (56 d), the $20 \%$ SMC also resulted in a more negative midday water potential than the $30 \%$ and $40 \%$ SMC. The $20 \%$ SMC plants were stressed at midday at the end of greenhouse production, but not at pre-dawn, and the $10 \%$ SMC plants were always stressed and never recovered from pre-dawn to midday. During the latter part of greenhouse production, the

Table 1. Plant height, node number, internode length, and days to first open flower for four soil moisture content (SMC) treatments on Angelonia angustifolia 'Angelface Blue' during the greenhouse production stage of the fall (3 Sept. to 29 Oct. 2010) and spring (25 Jan. to 11 May 2011) experiments in College Station, TX.

\begin{tabular}{|c|c|c|c|c|c|c|c|c|}
\hline \multirow[b]{2}{*}{ SMC (\%) } & \multicolumn{4}{|c|}{ Fall expt. } & \multicolumn{4}{|c|}{ Spring expt. } \\
\hline & $\begin{array}{c}\text { Plant } \\
\text { ht }(\mathrm{cm})\end{array}$ & $\begin{array}{l}\text { Node } \\
\text { (no.) }\end{array}$ & $\begin{array}{c}\text { Internode } \\
\text { length }(\mathrm{cm})\end{array}$ & $\begin{array}{l}\text { Days to first } \\
\text { open flower }\end{array}$ & $\begin{array}{l}\text { Plant } \\
\text { ht }(\mathrm{cm})\end{array}$ & $\begin{array}{l}\text { Node } \\
\text { (no.) }\end{array}$ & $\begin{array}{c}\text { Internode } \\
\text { length }(\mathrm{cm})\end{array}$ & $\begin{array}{l}\text { Days to first } \\
\text { open flower }\end{array}$ \\
\hline$\overline{40}$ & $50.5 \mathrm{a}^{\mathrm{z}}$ & $50 a$ & 1.0 & 15 & $41.4 \mathrm{a}$ & $43 a$ & $1.0 \mathrm{a}$ & 35 \\
\hline 30 & $45.0 \mathrm{~b}$ & $47 \mathrm{ab}$ & 1.0 & 15 & $34.0 \mathrm{~b}$ & $42 \mathrm{a}$ & $0.9 \mathrm{~b}$ & 35 \\
\hline 20 & $38.1 \mathrm{~b}$ & $43 \mathrm{~b}$ & 1.0 & 15 & $21.5 \mathrm{c}$ & $31 \mathrm{~b}$ & $0.7 \mathrm{~b}$ & 35 \\
\hline 10 & $35.0 \mathrm{c}$ & $35 \mathrm{c}$ & 0.9 & 15 & $16.2 \mathrm{~d}$ & $23 \mathrm{c}$ & $0.7 \mathrm{~b}$ & 35 \\
\hline Significance & $* * *$ & $* * *$ & NS & NS & $* * *$ & $* * *$ & $* * *$ & NS \\
\hline
\end{tabular}

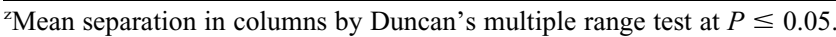

NS, ***Nonsignificant or significant at $P=0.001$, respectively.

Table 2. Fresh flower, bud, and senesced flower numbers for four soil moisture content (SMC) treatments on Angelonia angustifolia 'Angelface Blue' during the greenhouse production stage of the fall (3 Sept. to 29 Oct. 2010) and spring (25 Jan. to 11 May 2011) experiments in College Station, TX.

\begin{tabular}{|c|c|c|c|c|c|c|}
\hline \multirow[b]{2}{*}{ SMC (\%) } & \multicolumn{3}{|c|}{ Fall expt. } & \multicolumn{3}{|c|}{ Spring expt. } \\
\hline & $\begin{array}{c}\text { Fresh } \\
\text { flower (no.) }\end{array}$ & $\begin{array}{l}\text { Bud } \\
\text { (no.) }\end{array}$ & $\begin{array}{c}\text { Senesced } \\
\text { flower (no.) }\end{array}$ & $\begin{array}{c}\text { Fresh } \\
\text { flower (no.) }\end{array}$ & $\begin{array}{l}\text { Bud } \\
\text { (no.) }\end{array}$ & $\begin{array}{c}\text { Senesced } \\
\text { flower (no.) }\end{array}$ \\
\hline$\overline{40}$ & $36 a^{z}$ & $32 \mathrm{a}$ & $3 a b$ & $32 a$ & $33 a$ & 0.5 \\
\hline 30 & $31 \mathrm{ab}$ & $34 \mathrm{a}$ & $2 a$ & $28 \mathrm{a}$ & $28 \mathrm{~b}$ & 1.0 \\
\hline 20 & $28 \mathrm{~b}$ & $24 \mathrm{~b}$ & $6 \mathrm{bc}$ & $17 \mathrm{~b}$ & $20 \mathrm{c}$ & 1.0 \\
\hline 10 & $17 \mathrm{c}$ & $14 \mathrm{c}$ & $9 \mathrm{c}$ & $5 \mathrm{c}$ & $19 \mathrm{c}$ & 1.4 \\
\hline Significance & $* * *$ & $* *$ & $* *$ & $* * *$ & $* * *$ & NS \\
\hline
\end{tabular}

${ }^{\mathrm{z}}$ Mean separation in columns by Duncan's multiple range test at $P \leq 0.05$.

NS, **, ***Nonsignificant or significant at $P=0.01$ or 0.001 , respectively. 

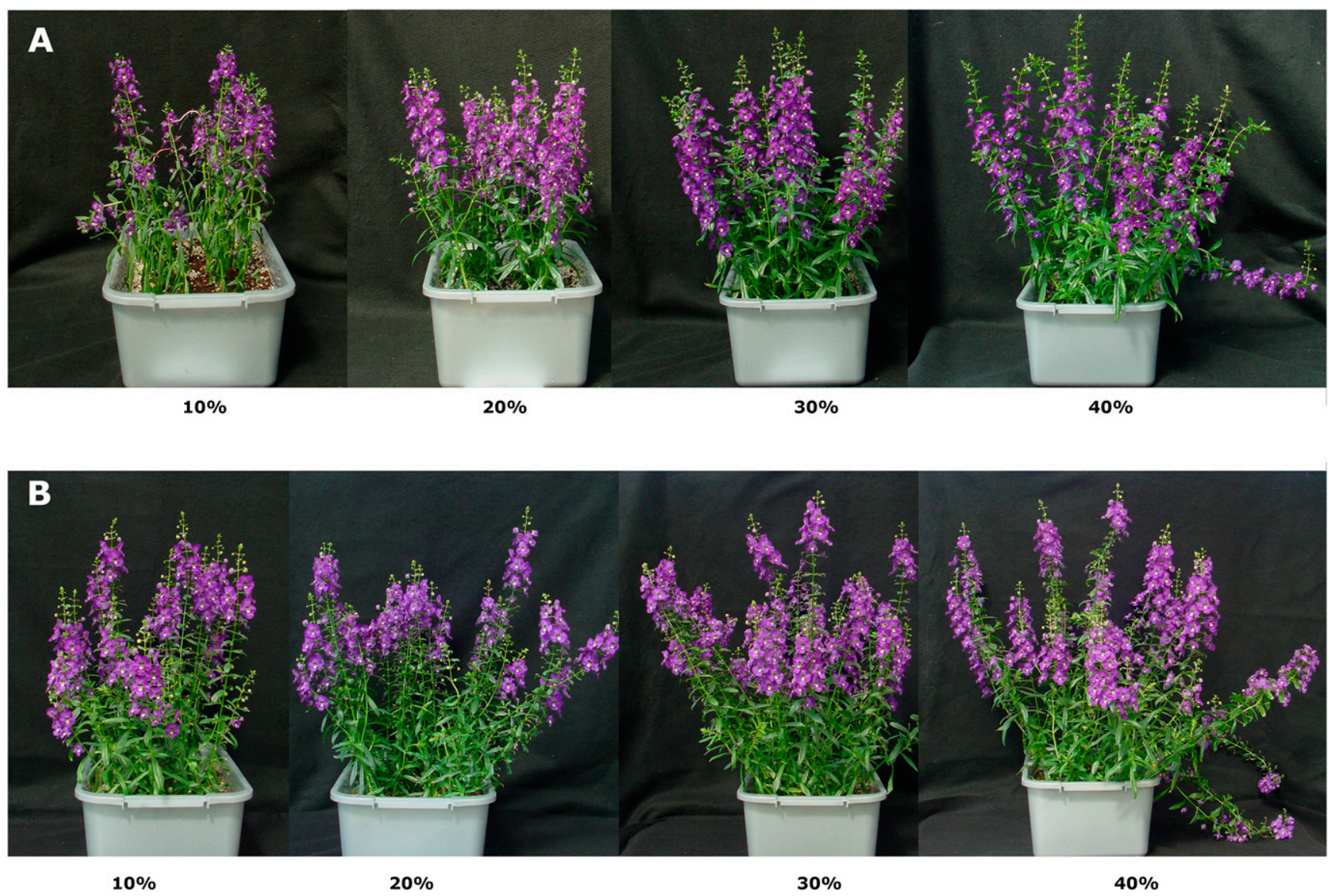

Fig. 1. Photographs of $10 \%, 20 \%, 30 \%$, and $40 \%$ soil moisture content (SMC) treatments of Angelonia angustifolia 'Angelface Blue' (A) at the end of 5 weeks of the greenhouse production stage and before the simulated shipping stage and (B) at the end of 3 weeks of the simulated retail stage in the fall (3 Sept. to 29 Oct. 2010) experiment in College Station, TX.

Table 3. Leaf chlorophyll index [Special Products Analysis Division (SPAD) values] on $3 \mathrm{~d}$ during the greenhouse production stage $(49,54$, and $56 \mathrm{~d})$, and on $2 \mathrm{~d}$ (61 and $90 \mathrm{~d})$ during the simulated retail stage for four soil moisture content (SMC) treatments on Angelonia angustifolia 'Angelface Blue' during the spring (25 Jan. to 11 May 2011) experiment in College Station, TX.

\begin{tabular}{lccccr}
\hline & \multicolumn{5}{c}{ SPAD values (Days of expt.) } \\
\cline { 2 - 6 } SMC (\%) & $49 \mathrm{~d}$ & $54 \mathrm{~d}$ & $56 \mathrm{~d}$ & $61 \mathrm{~d}$ & $90 \mathrm{~d}$ \\
\hline 40 & $50.6 \mathrm{~d}^{\mathrm{z}}$ & $53.8 \mathrm{~b}$ & $52.0 \mathrm{~b}$ & 50.3 & 53.7 \\
30 & $54.8 \mathrm{c}$ & $56.2 \mathrm{~b}$ & $54.9 \mathrm{a}$ & 53.3 & 50.9 \\
20 & $62.9 \mathrm{~b}$ & $64.9 \mathrm{a}$ & $61.8 \mathrm{a}$ & 55.0 & 53.4 \\
10 & $67.9 \mathrm{a}$ & $64.9 \mathrm{a}$ & $65.2 \mathrm{a}$ & 54.1 & 54.3 \\
Significance & $* * *$ & $* * *$ & $* * *$ & $\mathrm{NS}$ & $\mathrm{NS}$ \\
\hline
\end{tabular}

${ }^{2}$ Mean separation in columns by Duncan's multiple range test at $P \leq 0.05$.

NS, ${ }^{* *}$ Nonsignificant or significant at $P=0.001$, respectively.

$10 \%$ SMC resulted in wilting throughout the day, which negatively affected the postharvest quality of these plants.

Simulated shipping. After simulated shipping in the fall experiment, the total number of abscised flowers that had fallen into the shipping box and onto the root substrate surface was greatest for $40 \% \mathrm{SMC}$ and least for $10 \%$ SMC (Table 5). Overwatering in production can cause abscission of leaves and flowers (Nell, 1993). The lower SMC plants may have been more acclimated to the stressful conditions such as temperature fluctuations, low light intensities, and high ethylene levels in shipping. Plants in the Scrophulariaceae such as angelonia are sensitive to ethylene and thus flower abscission can be high during shipping (van Doorn, 2002).
Although the higher SMC plants abscised more flowers, there was no difference in percent of abscised flowers during shipping in either experiment indicating that angelonia abscised the same percentage of the total flowers regardless of the SMC. Also, simulated shipping in the dark did not bring about internode elongation because all internodes measured $1.0 \mathrm{~cm}$ or less before (Table 1) and after simulated shipping (Table 5).

Simulated retail. At termination of simulated retail in the fall (indiscriminate irrigation regimen) experiment, the $40 \%$ SMC had more fresh flowers than the other treatments and the $10 \%$ SMC had the least amount of senesced flowers (Table 6). The only treatment to continue to develop new buds during simulated retail was $10 \%$ SMC. Less senesced flowers and more buds in the $10 \%$ SMC plants could be an indication of acclimation to lower water levels.

During simulated retail in the fall experiment using the indiscriminant irrigation regimen, total volume of water applied to the $40 \% \mathrm{SMC}$ was $6.0 \mathrm{~L}$ and irrigation events occurred on 8 of $21 \mathrm{~d}$ (Table 7). The $10 \%$ SMC received $2.4 \mathrm{~L}$ at irrigation events on 5 different days. In the spring experiment using the limited irrigation regimen, total volume of water applied to the $40 \%$ SMC was $9.0 \mathrm{~L}$ and irrigation events occurred on 7 of $21 \mathrm{~d}$ (Table 7). The 10\% SMC plants never wilted and therefore were never watered in simulated retail. As observed during greenhouse production, the $40 \%$ plants were taller (Table 1) and required more water; therefore, they were watered more frequently and the total duration of watering was longer for these plants. Regardless of more irrigation, the $40 \%$ SMC plants in the fall experiment wilted in the afternoons during the later part of simulated retail. It is noteworthy that in the spring experiment, although the $10 \%$ SMC plants wilted during the greenhouse production stage, during the simulated retail stage, they never wilted and therefore were never watered during this time. EC during simulated retail was similar among SMC treatments (Table 7). 
Table 4. Total volume of water applied during all irrigation events, number of irrigation events, total irrigation duration, and electrical conductivity (EC) of the root substrate for four soil moisture content (SMC) treatments on Angelonia angustifolia 'Angelface Blue' during the greenhouse production stage in the fall (3 Sept. to 29 Oct. 2010) and spring (25 Jan. to 11 May 2011) experiments in College Station, TX. ${ }^{2}$

\begin{tabular}{|c|c|c|c|c|c|c|c|c|}
\hline \multirow[b]{2}{*}{$\begin{array}{l}\text { SMC } \\
(\%)\end{array}$} & \multicolumn{4}{|c|}{ Fall Expt. } & \multicolumn{4}{|c|}{ Spring Expt. } \\
\hline & $\begin{array}{c}\text { Total } \\
\text { volume }(\mathrm{L})\end{array}$ & $\begin{array}{c}\text { Number of } \\
\text { irrigation events }\end{array}$ & $\begin{array}{c}\text { Total irrigation } \\
\text { duration (s) }\end{array}$ & $\begin{array}{c}\mathrm{EC} \\
\left(\mathrm{dS} \cdot \mathrm{m}^{-1}\right)\end{array}$ & $\begin{array}{c}\text { Total } \\
\text { volume }(\mathrm{L})\end{array}$ & $\begin{array}{l}\text { Number of } \\
\text { irrigation events }\end{array}$ & $\begin{array}{c}\text { Total irrigation } \\
\text { duration (s) }\end{array}$ & $\begin{array}{c}\mathrm{EC} \\
\left(\mathrm{dS} \cdot \mathrm{m}^{-1}\right)\end{array}$ \\
\hline 40 & 14.7 & 38 & 2744 & 2.3 & 38.0 & 226 & 7286 & 1.5 \\
\hline 20 & 2.9 & 15 & 549 & 1.4 & 3.1 & 19 & 594 & 1.0 \\
\hline 10 & 1.9 & 11 & 349 & 1.3 & 1.0 & 6 & 352 & 1.0 \\
\hline
\end{tabular}

${ }^{z}$ Total volume of water applied, number of irrigation events, total irrigation, duration, and EC were obtained from the Acclima data logger.

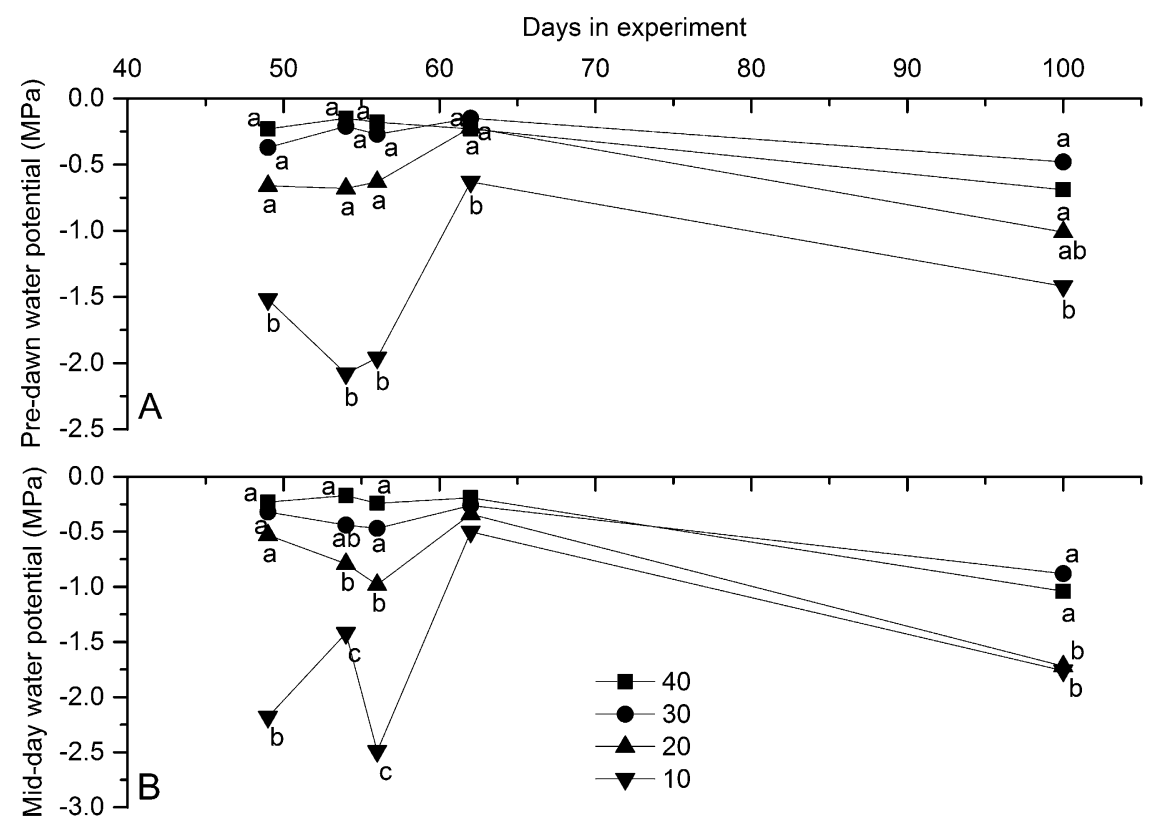

Fig. 2. Pre-dawn (A) and midday (B) water potential for four soil moisture content (SMC) treatments on Angelonia angustifolia 'Angelface Blue' at $49 \mathrm{~d}, 54 \mathrm{~d}, 56 \mathrm{~d}$ (greenhouse production stage), and $62 \mathrm{~d}$ and $100 \mathrm{~d}$ (simulated retail stage) in the spring (25 Jan. to 11 May 2011) experiment in College Station, TX. Mean separation by Duncan's multiple range test among treatments within day and time of measurements at $P \leq 0.05$. Mean totals with a common letter are not different.

Table 5. Total number of abscised flowers and abscised flower percentage (total number of abscised flowers after shipping divided by the total fresh and senesced flowers attached to the plant before shipping multiplied $\times 100$ ) after the $48 \mathrm{~h}$ simulated shipping and internode length during the simulated retail stage for the four soil moisture content (SMC) treatments on Angelonia angustifolia 'Angelface Blue' in the fall (3 Sept. to 29 Oct. 2010) and spring (25 Jan. to 11 May 2011) experiments in College Station, TX.

\begin{tabular}{lccccccc}
\hline & \multicolumn{3}{c}{ Fall expt. } & & \multicolumn{3}{c}{ Spring expt. } \\
\cline { 2 - 4 } SMC (\%) & $\begin{array}{c}\text { Total abscised } \\
\text { flower (no.) }\end{array}$ & $\begin{array}{c}\text { Abscised } \\
\text { flower }(\%)\end{array}$ & $\begin{array}{c}\text { Internode } \\
\text { length }(\mathrm{cm})\end{array}$ & $\begin{array}{c}\text { Total abscised } \\
\text { flower (no.) }\end{array}$ & $\begin{array}{c}\text { Abscised } \\
\text { flower }(\%)\end{array}$ & $\begin{array}{c}\text { Internode } \\
\text { length }(\mathrm{cm})\end{array}$ \\
\hline 40 & $20 \mathrm{a}^{\mathrm{z}}$ & 7 & 1.0 & & $39 \mathrm{a}$ & 35 & 0.8 \\
30 & $14 \mathrm{ab}$ & 5 & 0.9 & & $34 \mathrm{a}$ & 56 & 0.8 \\
20 & $12 \mathrm{ab}$ & 4 & 0.9 & & $15 \mathrm{~b}$ & 48 & 0.8 \\
10 & $7 \mathrm{~b}$ & 3 & 0.8 & & $8 \mathrm{~b}$ & 28 & 0.6 \\
Significance & $*$ & $\mathrm{NS}$ & NS & & $* * *$ & NS & NS \\
\hline
\end{tabular}

${ }^{\mathrm{z}}$ Mean separation in columns by Duncan's multiple range test at $P \leq 0.05$.

NS, $* * * *$ Nonsignificant or significant at $P=0.05$ or 0.001 , respectively.

Table 6. Fresh flower, bud, and senesced flower numbers for four soil moisture content (SMC) treatments on Angelonia angustifolia 'Angelface Blue' at the end of the 3-week simulated retail stage of the fall (3 Sept. to 29 Oct. 2010) experiment in College Station, TX.

\begin{tabular}{lccc}
\hline SMC (\%) & Fresh flower (no.) & Bud (no.) & Senesced flower (no.) \\
\hline 40 & $34 \mathrm{a}^{\mathrm{z}}$ & $16 \mathrm{~b}$ & $76 \mathrm{~b}$ \\
30 & $22 \mathrm{~b}$ & $16 \mathrm{~b}$ & $81 \mathrm{c}$ \\
20 & $25 \mathrm{~b}$ & $18 \mathrm{~b}$ & $67 \mathrm{ab}$ \\
10 & $19 \mathrm{~b}$ & $22 \mathrm{a}$ & $48 \mathrm{a}$ \\
Significance & $* * *$ & $* * *$ & $* * *$ \\
\hline
\end{tabular}

${ }^{\mathrm{z}}$ Mean separation in columns by Duncan's multiple range test at $P \leq 0.05$.

*** Significant at $P=0.001$.
At the termination of simulated retail in the fall experiment, the postharvest quality for the $30 \%$ and $40 \%$ SMC plants was observed to be low as a result of lodging stems (Fig. 1B). The postharvest quality for the $10 \%$ and $20 \%$ SMC plants was observed to be better because of their compact height with comparably long flowering portions of stem. At the termination of simulated retail in the spring experiment, the $10 \%, 30 \%$, and $40 \%$ SMC plants were observed to have low postharvest quality because the $30 \%$ and $40 \%$ SMC plants were tall and branched with lodged stems, whereas the $10 \%$ SMC plants were stunted. The $20 \%$ SMC postharvest quality was the highest because of their compact height. Throughout the simulated retail stage, there was no difference in darkness of leaf color among treatments as was seen during the production stage (Table 3).

At the end of simulated retail in the fall experiment, stem fresh and dry weight decreased with SMC levels (Table 8). As SMC levels decreased from $40 \%$ to $20 \%$, root fresh and dry weight decreased, but there was no further decrease from $20 \%$ to $10 \%$ SMC. There was no difference in shoot:root ratio among treatments. Our results are similar to those found for gaura (Burnett and van Iersel, 2008), impatiens, petunia, salvia, and vinca (Armitage and Kowalski, 1983; Eakes et al., 1991; Nemali and van Iersel, 2006), miniature roses (Williams et al., 1999, 2000), carnations (Álvarez et al., 2009), hibiscus (Hansen et al., 2005), and marigolds (van Iersel and Nemali, 2004). Conversely, strawberries (Klamkowski and Treder, 2006) grown under drought stress had similar root weights as controls.

Pre-dawn and midday water potentials during simulated retail in the fall experiment were not different among treatments (data not shown). This could be the result of all treatments being watered at $20 \%$ SMC (indiscriminant irrigation regimen). The $40 \%$ SMC plants wilted in the afternoons but had a similar water potential as lower SMC treatments. The WUE for the $10 \%$ and $20 \%$ SMC plants was higher than the $40 \%$ plants in the fall experiments (Fig. 3A). Increase in WUE has been shown to be a frequent response of plants in drought conditions and is considered a mechanism for drought resistance (Starman and Lombardini, 2006), so it is possible the lower SMC plants became acclimated to drought stress.

During simulated retail (62 d and $100 \mathrm{~d})$ in the spring experiment, $10 \% \mathrm{SMC}$ resulted 
Table 7. Total volume of water applied during all irrigation events, number of irrigation events, total irrigation duration, and electrical conductivity (EC) of the root substrate for four soil moisture content (SMC) treatments on Angelonia angustifolia 'Angelface Blue' during the simulated retail stage in the fall (3 Sept. to 29 Oct. 2010) experiment using the indiscriminant irrigation regime and the spring (25 Jan. to 11 May 2011) experiment using the limited irrigation regime in College Station, TX.,y

\begin{tabular}{|c|c|c|c|c|c|c|c|c|}
\hline \multirow[b]{2}{*}{$\begin{array}{l}\text { SMC } \\
(\%)\end{array}$} & \multicolumn{4}{|c|}{ Fall expt. } & \multicolumn{4}{|c|}{ Spring expt. } \\
\hline & $\begin{array}{c}\text { Total } \\
\text { volume }(\mathrm{L})\end{array}$ & $\begin{array}{l}\text { Number of } \\
\text { irrigation } \\
\text { events (d) }\end{array}$ & $\begin{array}{c}\text { Total } \\
\text { irrigation } \\
\text { duration (s) }\end{array}$ & $\begin{array}{c}\mathrm{EC} \\
\left(\mathrm{dS} \cdot \mathrm{m}^{-1}\right)\end{array}$ & $\begin{array}{c}\text { Total } \\
\text { volume }(\mathrm{L})\end{array}$ & $\begin{array}{l}\text { Number of } \\
\text { irrigation } \\
\text { events (d) }\end{array}$ & $\begin{array}{c}\text { Total } \\
\text { irrigation } \\
\text { duration (s) }\end{array}$ & $\begin{array}{c}\mathrm{EC} \\
\left(\mathrm{dS} \cdot \mathrm{m}^{-1}\right)\end{array}$ \\
\hline 40 & 6.0 & 8 & 1140 & 1.7 & 9.0 & 7 & 1680 & 2.1 \\
\hline 30 & 4.7 & 7 & 900 & 1.6 & 5.5 & 3 & 1020 & 1.9 \\
\hline 20 & 5.1 & 6 & 960 & 1.6 & 3.0 & 1 & 180 & 1.9 \\
\hline 10 & 2.4 & 5 & 480 & 1.5 & 0.0 & 0 & 0 & 1.8 \\
\hline
\end{tabular}

zTotal volume of water applied, number of irrigation events, total irrigation, duration, and EC were obtained from the Acclima data logger.

${ }^{\mathrm{y}}$ Indiscriminate $=$ water all treatments the same to $20 \% \mathrm{SMC}$; Limited $=$ water when plants in treatment wilt.

Table 8. Stem and root fresh and dry weight, and shoot:root ratios for four soil moisture content (SMC) treatments on Angelonia angustifolia 'Angelface Blue' at the termination of the fall (3 Sept. to 29 Oct. 2010) experiment in College Station, TX.

\begin{tabular}{lccccc}
\hline $\begin{array}{l}\text { SMC } \\
(\%)\end{array}$ & $\begin{array}{c}\text { Stem fresh } \\
\text { wt }(\mathrm{g})\end{array}$ & $\begin{array}{c}\text { Stem dry } \\
\text { wt }(\mathrm{g})\end{array}$ & $\begin{array}{c}\text { Root fresh } \\
\text { wt }(\mathrm{g})\end{array}$ & $\begin{array}{c}\text { Root dry } \\
\text { wt }(\mathrm{g})\end{array}$ & $\begin{array}{c}\text { Shoot:root } \\
\text { ratio }\end{array}$ \\
\hline 40 & $47.7 \mathrm{a}^{\mathrm{z}}$ & $7.4 \mathrm{a}$ & $21.6 \mathrm{a}$ & $1.9 \mathrm{a}$ & 4.98 \\
30 & $38.1 \mathrm{~b}$ & $6.3 \mathrm{~b}$ & $15.1 \mathrm{~b}$ & $1.3 \mathrm{~b}$ & 5.42 \\
20 & $37.1 \mathrm{~b}$ & $5.0 \mathrm{c}$ & $11.8 \mathrm{c}$ & $1.0 \mathrm{c}$ & 7.23 \\
10 & $28.6 \mathrm{c}$ & $3.8 \mathrm{~d}$ & $11.9 \mathrm{c}$ & $1.0 \mathrm{c}$ & 5.68 \\
Significance & $* * *$ & $* * *$ & $* * *$ & $* * *$ & NS \\
\hline
\end{tabular}

${ }^{z}$ Mean separation in columns by Duncan's multiple range test at $P \leq 0.05$.

NS, ***Nonsignificant or significant at $P=0.001$, respectively.

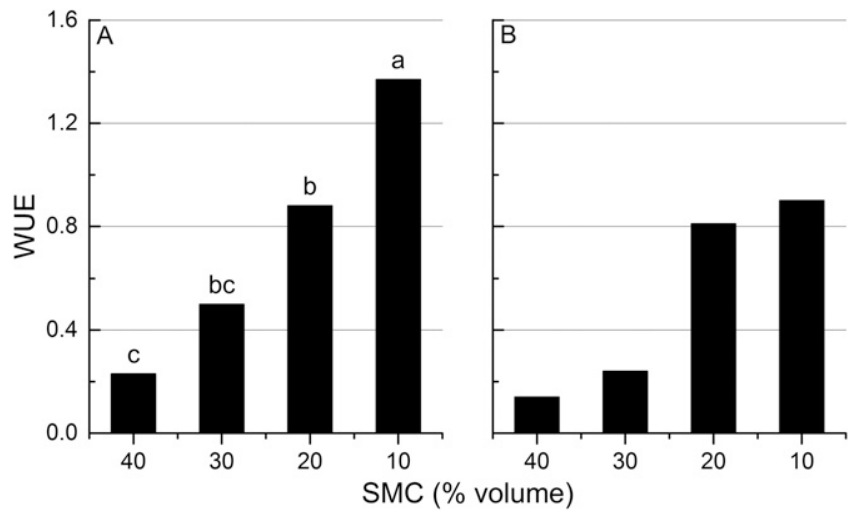

Fig. 3. Water use efficiency (WUE) during greenhouse production for the fall (3 Sept. to 29 Oct. 2010) experiment (A) and the spring (25 Jan. to 11 May 2011) experiment (B) for four soil moisture content (SMC) treatments on Angelonia angustifolia 'Angelface Blue' in College Station, TX. Mean separation by Duncan's multiple range test among treatments for each experiment at $P \leq 0.05$. Means with a common letter are not different.

in lower pre-dawn water potential at $62 \mathrm{~d}$ (Fig. $2 \mathrm{~A})$, but during midday, there was no difference among treatments at $62 \mathrm{~d}$ (Fig. 2B). At termination of simulated retail $(100 \mathrm{~d})$, the $10 \%$ SMC plants were the most stressed during pre-dawn, and both the $10 \%$ and $20 \%$ SMC plants were the most stressed during midday. Lower water potentials for drought-stressed plants compared with controls is a common occurrence and was also found in strawberries (Klamkowski and Treder, 2006) and in carnations (Álvarez et al., 2009). There was no difference in WUE between treatments in the spring (Fig. 3B).

In conclusion, decreasing irrigation reduced the height of angelonia with no effect on days to first open flower. Growing plants with lower SMC levels without extending production time would be advantageous to growers. Turnover of crops is vital to greenhouse production therefore adjust the level of drought stress to reduce plant height without damage to plant postharvest quality.

\section{Literature Cited}

Álvarez, S., A. Navarro, S. Bañón, and M.J. SánchezBlanco. 2009. Regulated deficit irrigation in potted Dianthus plants: Effects of severe and moderate water stress on growth and physiological responses. Sci. Hort. 122: 579-585.

Armitage, A.M. and T. Kowalski. 1983. Effect of irrigation frequency during greenhouse production on the postproduction quality of Petunia hybrida Vilm. J. Amer. Soc. Hort. Sci. 108:118-121.

Beach, S.E., T.W. Starman, K.L. Eixmann, H.B. Pemberton, and K.M. Heinz. 2009. Reduced end-of-production fertilization rate increased postproduction shelf life of containerized vegetative annuals. HortTechnology 19:158-167.

Burnett, E. and M. van Iersel. 2008. Morphology and irrigation efficiency of Gaura lindheimeri grown with capacitance sensor-controlled irrigation. HortScience 43:1555-1560.

Eakes, D.J., R.D. Wright, and J.R. Seiler. 1991. Moisture stress conditioning effects on Salvia splendens 'Bonfire'. J. Amer. Soc. Hort. Sci. 116:716-719.

Hansen, C.W., K.K. Petersen, and A.K. Larsen. 2005. Effects of reduced nutrient and water availability on plant growth and post-production quality of Hibiscus rosa-sinensis. Acta Hort. 669:269-274.

Harris, R.W. 1992. Root-shoot ratios. J. Aboricult. 18:39-42.

Jones, M.L. 2002. Postproduction care and handling. Ohio Florists' Assoc. Bul. 872.

Klamkowski, K. and W. Treder. 2006. Morphological and physiological responses of strawberry plants to water stress. Agr. Conspec. Sci. 71:159-165.

Markwell, J.M., J.C. Osterman, and J.L. Mitchell 1995. Calibration of the Minolta SPAD-505 leaf chlorophyll meter. Photosynth. Res. 46:467-472.

Nell, T.A. 1993. Flowering potted plants: Prolonging shelf life performance. Ball Publishing, Batavia, IL.

Nemali, S. and M. van Iersel. 2004. Moisture stress for growth control: Physiological responses of salvia (Salvia splendens) and vinca (Catharanthus roseus). SNA Res. Conf. 49:618-623.

Nemali, S. and M. van Iersel. 2005. A novel automated system for irrigation and plants simulating drought stress in potted plants. SNA Res. Conf. 50:690-695.

Nemali, S. and M. van Iersel. 2006. An automated system for controlling drought stress and 
irrigation in potted plants. Sci. Hort. 110: 292-297.

Starman, T.W. and L. Lombardini. 2006. Growth, gas exchange, and chlorophyll fluorescence of four ornamental herbaceous perennials during water deficit conditions. J. Amer. Soc. Hort. Sci. 131: 469-475. van Doorn, W.G. 2002. Effect of ethylene on flower abscission: A survey. Ann. Bot. (Lond.) 89:689-693.

van Iersel, M.W. and K.S. Nemali. 2004. Drought stress can produce small but not compact marigolds. HortScience 39:1298-1301.

Williams, M.A., E. Rosenqvist, and M. Buchhave. 1999. Response of potted miniature roses
(Rosa $\times$ hybrida) to reduced water availability during production. J. Hort. Sci. Biotechnol. 74:301-308.

Williams, M.H., E. Rosenqvist, and M. Buchhave. 2000. The effect of reducing production water availability on the post-production quality of potted miniature roses $($ Rosa $\times$ hybrida $)$. Postharvest Biol. Technol. 18:143-150. 